\title{
Factors associated with basal metabolic rate in patients with Type 2 (non-insulin-dependent) diabetes mellitus
}

\author{
A. Franssila-Kallunki and L. Groop \\ Helsinki University Hospital, Fourth Department of Medicine, Helsinki, Finland
}

\begin{abstract}
Summary. To examine determinants of basal metabolic rate we studied 66 Type 2 (non-insulin-dependent) diabetic and 24 healthy age- and weight-matched control subjects with indirect calorimetry and infusion of [ $\left.{ }^{3} \mathrm{H}-3-\right]$ glucose. Eight Type 2 diabetic patients were re-studied after a period of insulin therapy. Basal metabolic rate was higher in Type 2 diabetic patients than in control subjects $(102.8 \pm 1.9 \mathrm{~J} \cdot \mathrm{kg}$ $\left.\mathrm{LBM}^{-1} \cdot \mathrm{min}^{-1} \mathrm{vs} 90.7 \pm 2.8 \mathrm{~J} \cdot \mathrm{kg} \mathrm{LBM}{ }^{-1} \cdot \min ^{-1} ; p<0.01\right)$ and decreased significantly with insulin therapy $(p<0.01)$. The basal rate of hepatic glucose production was higher in Type 2 diabetic patients than in control subjects $(1044.0 \pm 29.9$ vs $789.3 \pm 41.7 \mu \mathrm{mol} / \mathrm{min} ; p<0.001)$ and decreased after insulin therapy $(p<0.01)$. Hepatic glucose production correlated positively with basal metabolic rate both in Type 2 diabetic patients $(r=0.49 ; p<0.001)$ and in control subjects $(r=0.50$;
\end{abstract}

$p<0.05)$. Lipid oxidation was increased in Type 2 diabetic patients compared with control subjects $(1.68 \pm 0.05$ vs $\left.1.37 \pm 0.08 \mu \mathrm{mol} \cdot \mathrm{kg} \mathrm{LBM}{ }^{-1} \cdot \mathrm{min}^{-1} ; p<0.01\right)$ and decreased significantly after insulin therapy $(p<0.05)$. The rate of lipid oxidation correlated positively with basal metabolic rate both in Type 2 diabetic patients $(r=0.36 ; p<0.01)$ and in control subjects $(r=0.51 ; p<0.01)$. These data demonstrate that basal metabolic rate, rates of hepatic glucose production and lipid oxidation are interrelated in Type 2 diabetic patients. A reduction of the hepatic glucose production, however, is associated with a reduction in lipid oxidation, which in turn, may result in a reduction in basal metabolic rate.

Key words: Basal metabolic rate, Type 2 (non-insulin-dependent) diabetes mellitus.
Patients with Type 2 (non-insulin-dependent) diabetes mellitus and fasting hyperglycaemia are usually characterized by an elevated basal metabolic rate (BMR) [1]. An improvement in glycaemic control achieved by oral hypoglycaemic agents or hypocaloric diet is frequently followed by a reduction in BMR [1-3]. This can be partially attributed to a reduced loss of calories in the urine, i.e. a reduction in glucosuria. On the other hand, even patients with no glucosuria can present with an elevated BMR. Therefore, other factors must be responsible. Fasting hyperglycaemia ensues as a consequence of increased hepatic glucose production (HGP) [4], which is primarily due to an increased rate of gluconeogenesis [5]. Gluconeogenesis is an energy expensive process [6], which could easily contribute to the increase in energy expenditure observed in these patients. It has also been suggested that an increased rate of lipid oxidation could contribute to the increased rate of hepatic glucose production [7], since betaoxidation of non-esterified fatty acids (NEFA) provide the abundance of ATP required for gluconeogenesis [8]. This was supported by a positive correlation between the rate of lipid oxidation and the rate of hepatic glucose pro- duction in individuals with normal and elevated (diabetic) blood glucose concentrations [7]. Limited data are available on how lipid oxidation and hepatic glucose production are related to the BMR in patients with Type 2 diabetes $[1,9,10]$. Whether these factors influence BMR similarly in Type 2 diabetic and control subjects is also not known.

The present study was therefore designed to examine whether the same factors were associated with BMR in hyperglycaemic non-obese Type 2 diabetic patients and healthy control subjects. To examine whether these factors could be influenced by treatment, a subset of diabetic patients was re-studied after having achieved near-normoglycaemia with insulin therapy.

\section{Subjects and methods}

\section{Subjects}

Sixty-six patients ( 32 females and 34 males) with Type 2 diabetes of 8 years $(0-26$ years) participated in the study. They were all treated with either diet alone or oral hypoglycaemic agents or both. The 
Table 1. The clinical characteristics of the subjects

\begin{tabular}{lcc}
\hline & $\begin{array}{l}\text { Type } 2 \\
\text { (non-insulin-dependent) } \\
\text { diabetic patients }\end{array}$ & $\begin{array}{l}\text { Healthy } \\
\text { subjects }\end{array}$ \\
\hline$n$ (females/males) & $32 / 34$ & $10 / 14$ \\
Age (years) & $59 \pm 1$ & $58 \pm 2$ \\
Body mass index $\left(\mathrm{kg} / \mathrm{m}^{2}\right)$ & $25.5 \pm 0.3$ & $25.3 \pm 0.5$ \\
Weight $(\mathrm{kg})$ & $73.3 \pm 1.3$ & $75.2 \pm 2.2$ \\
Lean body mass $(\mathrm{kg})$ & $48.2 \pm 1.2$ & $50.9 \pm 2.0$ \\
Fat percentage $(\%)$ & $34.2 \pm 1.2$ & $32.5 \pm 1.6$ \\
\hline
\end{tabular}

Table 2. Fasting metabolic characteristics of the subjects

\begin{tabular}{|c|c|c|}
\hline & $\begin{array}{l}\text { Type } 2 \\
\text { (non-insulin-dependent) } \\
\text { diabetic patients }\end{array}$ & $\begin{array}{l}\text { Healthy } \\
\text { subjects }\end{array}$ \\
\hline$n$ & 66 & 24 \\
\hline $\begin{array}{l}\text { Plasma glucose } \\
(\mathrm{mmol} / \mathrm{l})\end{array}$ & $10.5 \pm 0.4^{\mathrm{a}}$ & $5.0 \pm 0.1$ \\
\hline $\mathrm{HbA}_{1 \mathrm{c}}(\%)$ & $7.6 \pm 0.2^{\mathrm{a}}$ & $5.3 \pm 0.1$ \\
\hline $\begin{array}{l}\text { Serum insulin } \\
(\mathrm{pmol} / \mathrm{l})\end{array}$ & $64 \pm 5^{6}$ & $37 \pm 4$ \\
\hline $\begin{array}{l}\text { Serum cholesterol } \\
(\mathrm{mmol} / \mathrm{l})\end{array}$ & $6.5 \pm 0.2$ & $6.1 \pm 0.2$ \\
\hline $\begin{array}{l}\text { Serum HDL-cholesterol } \\
(\mathrm{mmol} / 1)\end{array}$ & $1.30 \pm 0.04$ & $1.28 \pm 0.08$ \\
\hline $\begin{array}{l}\text { Serum triglycerides } \\
\text { (mmol/) }\end{array}$ & $2.09 \pm 0.17^{\mathrm{c}}$ & $1.55 \pm 0.16$ \\
\hline Serum NEFA $(\mu \mathrm{mol} / 1)$ & $700 \pm 25$ & $646 \pm 40$ \\
\hline
\end{tabular}

${ }^{\mathrm{a}} \mathrm{p}<0.01,{ }^{\mathrm{b}} \mathrm{p}<0.01$ and ${ }^{\mathrm{c}} \mathrm{p}<0.05$ vs healthy subjects

antidiabetic medication was stopped one week before the studies. Twenty-four age- and weight-matched healthy individuals (10 female and 14 male) with no family history of diabetes served as control subjects. The clinical and metabolic characteristics of the subjects are shown in Tables 1 and 2. Eight Type 2 diabetic patients were re-studied after improved glycaemic control with insulin therapy for a 12-month duration. Their clinical and metabolic characteristics are shown in Table 3.

The study protocol was approved by the ethical committee of the Fourth Department of Medicine, Helsinki University Hospital, Helsinki, Finland.

\section{Methods}

All subjects were studied with indirect calorimetry to obtain measures of substrate oxidation and BMR and with $\left[{ }^{3} \mathrm{H}-3\right.$ - $]$ glucose infusion to quantitate hepatic glucose production. Lean body mass was measured with tritiated water technique.

Hepatic glucose production was measured by the isotope dilution technique using [ ${ }^{3} \mathrm{H}-3$ - $]$ glucose (specific activity $7.8 \mathrm{Ci} / \mathrm{mmol}$; Amersham International, Amersham, Bucks, UK) administered as primed constant $(0.25 \mu \mathrm{Ci} / \mathrm{min})$ infusion for $150 \mathrm{~min}$. The bolus dose was adjusted according to the degree of fasting hyperglycaemia (25$50 \mu \mathrm{Ci}$ ). Blood samples for determination of [ $\left.{ }^{3} \mathrm{H}-3-\right]$ glucose specific activity were obtained at 10 -min intervals during the last $30 \mathrm{~min}$.

Indirect calorimetry was employed during $30 \mathrm{~min}$ to estimate net rates of carbohydrate and lipid oxidation and energy expenditure [11]- A computerized, open-circuit system was used to measure gas exchange through a transparent plastic canopy (Deltatrac, Datex, Helsinki, Finland). Flow was measured by the air-dilution method, carbon dioxide concentration by a conventional infrared detector and oxygen concentration by a fast differential paramagnetic oxygen sensor. The monitor has a precision of $2.6 \%$ for oxygen consumption and $1.0 \%$ for carbon dioxide production. Protein oxidation was calculated from the urinary urea nitrogen excretion.

Lean body mass was determined with the tritiated water dilution technique [12]. Briefly, $40 \mu \mathrm{Ci}$ of tritiated water (Amersham) diluted in normal saline was given as an intravenous injection. Blood samples for determination of tritiated water specific activity in plasma were drawn before and 80,100 and $120 \mathrm{~min}$ after the injection.

\section{Analytical determinations}

The plasma glucose concentration was measured by the glucose oxidase method using a Beckman glucose analyzer II (Beckman Instruments, Fullerton, Calif., USA). Glycohaemoglobin concentration in blood $\left(\mathrm{HbA}_{1 \mathrm{c}}\right)$ was measured by high pressure liquid chromatography. The reference level for the assay was $5-7 \%$. Serum insulin was measured by a double-antibody radioimmunoassay (Pharmacia, Uppsala, Sweden). Plasma NEFA were measured with the microfluorometric method by Miles et al. [13]. $\left[{ }^{3} \mathrm{H}-3\right]$-glucose specific activity was measured in duplicate on supernatants of $1 \mathrm{~mol}$ perchloric acid extracts of plasma samples, after evaporation of radiolabelled water.

\section{Calculations}

Basal hepatic glucose production was calculated by dividing the $\left[{ }^{3} \mathrm{H}-\right.$ 3-]glucose infusion rate by the steady-state plateau of [ $\left.{ }^{3} \mathrm{H}-3-\right]$ glucose specific activity achieved during the last $30 \mathrm{~min}$ of the tracer infusion period.

Net glucose, lipid and protein oxidation rates were calculated from indirect calorimetric measurements [11] and urinary urea nitrogen excretion.

Total body water was calculated from steady-state kinetic data assuming that $1 \mathrm{ml}$ of plasma contains $93 \%$ water. Lean body mass

Table 3. Clinical and metabolic characteristics of eight insulintreated Type 2 (non-insulin-dependent) diabetic patients before and after insulin therapy

\begin{tabular}{|c|c|c|}
\hline & $\begin{array}{l}\text { Before insulin } \\
\text { therapy }\end{array}$ & $\begin{array}{l}\text { After insulin } \\
\text { therapy }\end{array}$ \\
\hline Body mass index $\left(\mathrm{kg} / \mathrm{m}^{2}\right)$ & $28.2 \pm 1.2$ & $29.6 \pm 1.1^{a}$ \\
\hline Weight (kg) & $75.6 \pm 4.9$ & $79.5 \pm 4.9^{\mathrm{a}}$ \\
\hline Lean body mass $(\mathrm{kg})$ & $44.3 \pm 3.8$ & $46.7 \pm 3.8$ \\
\hline $\begin{array}{l}\text { Plasma glucose } \\
(\mathrm{mmol} / \mathrm{l})\end{array}$ & $15.6 \pm 0.8$ & $9.3 \pm 1.0^{b}$ \\
\hline $\mathrm{HbA}_{1 \mathrm{c}}$ & $9.1 \pm 0.3$ & $7.4 \pm 0.4^{b}$ \\
\hline $\begin{array}{l}\text { Serum insulin } \\
\text { (pmol/1) }\end{array}$ & $84 \pm 11$ & $132 \pm 22$ \\
\hline $\operatorname{NEFA}(\mu \mathrm{mol} / 1)$ & $674 \pm 54$ & $818 \pm 71$ \\
\hline $\begin{array}{l}\text { Hepatic glucose production } \\
(\mu \mathrm{mol} / \mathrm{min})\end{array}$ & $1133 \pm 92$ & $983 \pm 80^{a}$ \\
\hline $\begin{array}{l}\text { Glucose oxidation } \\
\left(\mu \mathrm{mol} \cdot \mathrm{kg} \mathrm{LBM}^{-1} \cdot \mathrm{min}^{-1}\right)\end{array}$ & $9.6 \pm 1.1$ & $11.6 \pm 1.1$ \\
\hline $\begin{array}{l}\text { Lipid oxidation } \\
\left(\mu \mathrm{mol} \cdot \mathrm{kg} \mathrm{LBM}^{-1} \cdot \min ^{-1}\right)\end{array}$ & $2.0 \pm 0.1$ & $1.4 \pm 0.1^{b}$ \\
\hline $\begin{array}{l}\text { Basal metabolic } \\
\text { rate }(\mathrm{kJ} / \mathrm{min})\end{array}$ & $5.0 \pm 0.3$ & $4.7 \pm 0.3$ \\
\hline $\begin{array}{l}\text { Basal metabolic rate } \\
\left(\mathrm{J} \cdot \mathrm{kg} \mathrm{LBM}^{-1} \cdot \mathrm{min}^{-1}\right)\end{array}$ & $115.5 \pm 5.6$ & $103.1 \pm 5.7^{\mathrm{a}}$ \\
\hline
\end{tabular}


Table 4. Basal metabolic rates in Type 2 (non-insulin-dependent) diabetic and healthy subjects

\begin{tabular}{|c|c|c|}
\hline & $\begin{array}{l}\text { Type } 2 \\
\text { (non-insulin-dependent) } \\
\text { diabetic patients }\end{array}$ & $\begin{array}{l}\text { Healthy } \\
\text { subjects }\end{array}$ \\
\hline$n$ & 66 & 24 \\
\hline $\begin{array}{l}\text { Hepatic glucose production } \\
(\mu \mathrm{mol} / \mathrm{min})\end{array}$ & $1044 \pm 30^{\mathrm{a}}$ & $789 \pm 42$ \\
\hline $\begin{array}{l}\text { Glucose oxidation } \\
\left(\mu \mathrm{mol} \cdot \mathrm{kg} \mathrm{LBM} \mathrm{LB}^{-1} \cdot \mathrm{min}^{-1}\right)\end{array}$ & $9.4 \pm 0.4$ & $9.8 \pm 0.5$ \\
\hline 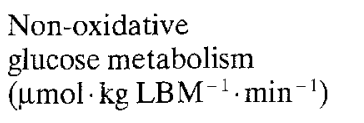 & $12.9 \pm 0.7^{\mathrm{a}}$ & $5.9 \pm 0.8$ \\
\hline 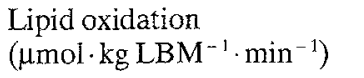 & $1.7 \pm 0.1^{b}$ & $1.4 \pm 0.1$ \\
\hline $\begin{array}{l}\text { Basal metabolic } \\
\text { rate }(\mathrm{kJ} / \mathrm{min})\end{array}$ & $4.8 \pm 0.1$ & $4.6 \pm 0.2$ \\
\hline $\begin{array}{l}\text { Basal metabolic rate } \\
\left(\mathrm{J} \cdot \mathrm{kg} \mathrm{LBM}^{-1} \cdot \mathrm{min}^{-1}\right)\end{array}$ & $102.8 \pm 1.9^{\mathrm{b}}$ & $90.7 \pm 2.8$ \\
\hline
\end{tabular}

${ }^{\mathrm{a}} \mathrm{p}<0.001$ and ${ }^{\mathrm{b}} \mathrm{p}<0.01$ vs healthy subjects

Table 5. Simple correlation coefficients $(r)$ relating clinical and metabolic characteristics with basal metabolic rate in control subjects

\begin{tabular}{|c|c|c|}
\hline & \multicolumn{2}{|c|}{ Basal metabolic rate } \\
\hline & $\overline{\mathrm{kJ} / \min }$ & $\mathrm{J} \cdot \mathrm{kg} \mathrm{LBM}^{-1} \cdot \mathrm{min}^{-1}$ \\
\hline Age (years) & $-0.64^{\mathrm{a}}$ & -0.02 \\
\hline Weight (kg) & $0.71^{\mathrm{a}}$ & -0.23 \\
\hline Lean body mass (kg) & $0.67^{2}$ & $-0.53^{b}$ \\
\hline Body mass index $\left(\mathrm{kg} / \mathrm{m}^{2}\right)$ & $0.44^{\mathrm{c}}$ & -0.04 \\
\hline Fat mass $(\%)$ & -0.26 & $0.62^{\mathrm{a}}$ \\
\hline $\begin{array}{l}\text { Cholesterol } \\
(\mathrm{mmol} / \mathrm{l})\end{array}$ & -0.32 & $-0.48^{c}$ \\
\hline $\begin{array}{l}\text { Triglycerides } \\
(\mathrm{mmol} / \mathrm{l})\end{array}$ & $0.41^{\circ}$ & -0.20 \\
\hline $\mathrm{BHGP}(\mu \mathrm{mol} / \mathrm{min})$ & $0.50^{\mathrm{c}}$ & -0.14 \\
\hline BGOX $(\mu \mathrm{mol} / \mathrm{min})$ & $0.41^{c}$ & $-0.44^{c}$ \\
\hline $\begin{array}{l}\text { BGOX } \\
\left(\mu \mathrm{mol} \cdot \mathrm{kg} \mathrm{LBM}^{-1} \cdot \mathrm{min}^{-1}\right)\end{array}$ & -0.06 & -0.20 \\
\hline $\operatorname{BLOX}(\mu \mathrm{mol} / \mathrm{min})$ & $0.84^{\mathrm{a}}$ & $0.57^{\mathrm{b}}$ \\
\hline $\begin{array}{l}\mathrm{BLOX} \\
\left(\mu \mathrm{mol} \cdot \mathrm{kg} \mathrm{LBM}^{-1} \cdot \min ^{-1}\right)\end{array}$ & $0.51^{\mathrm{b}}$ & $0.76^{a}$ \\
\hline $\begin{array}{l}\text { BPOX } \\
\left(\mu \mathrm{mol} \cdot \mathrm{kg} \mathrm{LBM} M^{-1} \cdot \mathrm{min}^{-1}\right)\end{array}$ & -0.09 & 0.39 \\
\hline
\end{tabular}

${ }^{\mathrm{a}} \mathrm{p}<0.001,{ }^{\mathrm{b}} \mathrm{p}<0.01,{ }^{\mathrm{c}} \mathrm{p}<0.05$

BHGP, Basal hepatic glucose production; BGOX, basal glucose oxidation; BLOX, basal lipid oxidation; BPOX, basal protein oxidation

was obtained by dividing total body water by 0.73 , since the lean body mass contains approximately $73 \%$ water. Fat mass was calculated as the difference between body weight and lean body mass.

\section{Statistical analysis}

Data are expressed as mean and range or mean \pm SEM. Statistical analyses have been performed using BMDP computer programs $(3 \mathrm{D}, 6 \mathrm{D}, 2 \mathrm{R})$. Differences between the groups were tested by Mann-
Whitney rank sum test and correlations by linear regression analysis. To examine which variables were independently associated with BMR, variables which significantly correlated with BMR in the univariate analysis, were included in a multivariate analysis with $B M R$ as dependent variable.

\section{Results}

The basal rate of hepatic glucose production was enhanced by $32 \%$ in Type 2 diabetic patients compared with healthy control subjects $(p<0.001)$ (Table 4$)$. The rate of lipid oxidation was increased by $21 \%$ in the Type 2 diabetic patients compared with the healthy control subjects $(p<0.01)$ (Table 4$)$. In addition, the BMR expressed per $\mathrm{kg}$ lean body mass was enhanced by $13 \%$ in Type 2 diabetic patients compared with the healthy control subjects $(p<0.01)$, although the absolute rate of BMR did not differ between the two groups (Table 4).

Insulin therapy resulted in an increase in weight and improvement in glycaemic control (Table 3). Basal hepatic glucose production and energy expenditure decreased significantly after treatment $(p<0.01$ vs before insulin therapy) and the rate of lipid oxidation was normalized ( $p<0.05$ vs before the insulin therapy). In healthy subjects the BMR correlated positively with weight $(p<0.001)$, body mass index $(p<0.05)$, lean body mass $(p<0.001)$, triglycerides $(p<0.05)$, hepatic glucose production $(p<0.05)$, glucose oxidation $(p<0.05)$ and with lipid oxidation $(p<0.001)$ (Table 5). In these subjects the absolute rate of BMR was inversely correlated with age $(p<0.01)$. Similarly, in the Type 2 diabetic subjects, the absolute BMR was positively correlated with weight $(p<0.001)$, body mass index $(p<0.01)$, lean body mass $(p<0.001)$, hepatic glucose production $(p<0.001)$ and lipid oxidation $(p<0.001)$ and inversely correlated with age $(p<0.01)$ and glucose oxidation $(p<0.01)$ (Table 6$)$.

The multivariate analysis clearly demonstrated that in both control subjects (70\%) and in Type 2 diabetic patients $(63 \%)$ lipid oxidation accounted for the major part of BMR. Lean body mass explained $20 \%$ of BMR in healthy control subjects and $15 \%$ of BMR in Type 2 diabetic patients.

\section{Discussion}

The Type 2 diabetic patients had fasting hyperglycaemia and significantly higher rates of BMR expressed per $\mathrm{kg}$ lean body mass than age- and weight-matched healthy control subjects. After a $40 \%$ reduction of fasting plasma glucose with insulin in a subset of patients, the rate of BMR approached values observed in the control subjects. The results are thus in agreement with previously published data in Type 2 diabetic patients $[1,2,9,10,14]$, but our results also extend to the comparison of BMR in weightmatched lean Type 2 diabetic subjects.

Since fat tissue is metabolically relatively inactive, muscle reflected by lean body mass has been considered as a major determinant of BMR [10]. In support of this, lean body mass showed a strong correlation with BMR in 
Table 6. Simple correlation coefficients $(r)$ relating clinical and metabolic characteristics with basal metabolic rate in patients with Type 2 (non-insulin-dependent) diabetes

\begin{tabular}{|c|c|c|}
\hline & \multicolumn{2}{|c|}{ Basal metabolic rate } \\
\hline & $\mathrm{kJ} / \mathrm{min}$ & $\mathrm{J} \cdot \mathrm{kg} \mathrm{LBM}{ }^{-1} \cdot \mathrm{min}^{-1}$ \\
\hline Age (years) & $-0.35^{b}$ & 0.06 \\
\hline Weight (kg) & $0.68^{\mathrm{a}}$ & -0.25 \\
\hline Lean body mass $(\mathrm{kg})$ & $0.67^{\mathrm{a}}$ & $-0.66^{\mathrm{a}}$ \\
\hline Body mass index $\left(\mathrm{kg} / \mathrm{m}^{2}\right)$ & $0.38^{\mathrm{b}}$ & 0.08 \\
\hline Fat mass (\%) & -0.22 & $0.69^{\mathrm{a}}$ \\
\hline $\begin{array}{l}\text { Cholesterol } \\
(\mathrm{mmol} / \mathrm{l})\end{array}$ & -0.04 & $0.38^{\mathrm{b}}$ \\
\hline $\begin{array}{l}\text { Triglycerides } \\
(\mathrm{mmol} / \mathrm{l})\end{array}$ & 0.24 & 0.24 \\
\hline $\mathrm{BHGP}(\mu \mathrm{mol} / \mathrm{min})$ & $0.49^{\mathrm{a}}$ & -0.12 \\
\hline $\mathrm{BGOX}(\mu \mathrm{mol} / \mathrm{min})$ & 0.02 & $-0.28^{c}$ \\
\hline $\begin{array}{l}\text { BGOX } \\
\left(\mu \mathrm{mol} \cdot \mathrm{kg} \mathrm{LBM}^{-1} \cdot \mathrm{min}^{-1}\right)\end{array}$ & $-0.37^{b}$ & 0.14 \\
\hline $\operatorname{BLOX}(\mu \mathrm{mol} / \mathrm{min})$ & $0.83^{\mathrm{a}}$ & 0.23 \\
\hline $\begin{array}{l}\mathrm{BLOX} \\
\left(\mu \mathrm{mol} \cdot \mathrm{kg} \mathrm{LBM}^{-1} \cdot \mathrm{min}^{-1}\right)\end{array}$ & $0.36^{\mathrm{b}}$ & $0.75^{\mathrm{a}}$ \\
\hline $\begin{array}{l}\mathrm{BPOX} \\
\left(\mu \mathrm{mol} \cdot \mathrm{kg} \mathrm{LBM}^{-1} \cdot \mathrm{min}^{-1}\right)\end{array}$ & -0.14 & $0.49^{\mathrm{a}}$ \\
\hline
\end{tabular}

${ }^{\mathrm{a}} \mathrm{p}<0.001,{ }^{\mathrm{b}} \mathrm{p}<0.01,{ }^{\mathrm{c}} \mathrm{p}<0.05$

$\mathrm{BHGP}, \mathrm{Basal}$ hepatic glucose production; $\mathrm{BGOX}$, basal glucose oxidation; BLOX, basal lipid oxidation; BPOX, basal protein oxidation

both control and Type 2 diabetic subjects $(p<0.001)$. Obesity is usually associated with an increase in lean body mass, and therefore it has been difficult to discern from previous studies what is due to obesity and what is due to diabetes per se. However, differences in lean body mass cannot solely explain the differences in BMR between diabetic and control subjects, as lean body mass did not significantly differ between the two groups. In the multivariate analysis lean body mass could explain only $15 \%$ of the BMR in Type 2 diabetic patients and $20 \%$ in healthy control subjects, whereas lipid oxidation accounted for the major part of BMR. This is, of course, partially explained by the equation for calculating BMR from gas exchange measurements. Furthermore, a reduction in fasting hyperglycaemia achieved by insulin was associated with a reduction in BMR despite a tendency to increased lean body mass. Reduction in glycaemia achieved by tolazamide [1] and diet [14] also resulted in a reduction in BMR.

In both diabetic and control subjects the rate of hepatic glucose production correlated with BMR and the fasting plasma glucose concentration $(r=0.59 ; p<0.001)$. This suggests that the higher the fasting plasma glucose concentration the higher the rate of hepatic glucose production and the higher the rate of BMR. In diabetic subjects gluconeogenesis accounts for about $75 \%$ of hepatic glucose production [5]. The production of glucose by gluconeogenesis is an energy expensive process, since the production of $1 \mathrm{~mol}$ of glucose from pyruvate will require $6 \mathrm{~mol}$ of ATP. It is therefore likely that the necessary en- ergy was provided by the increased rate of lipid oxidation, as the rate of lipid oxidation correlated positively both with BMR and hepatic glucose production. This was further supported by the strong relationship between the rate of lipid oxidation and BMR as demonstrated in the multivariate analysis. There are several other mechanisms by which an increased rate of lipid oxidation could stimulate gluconeogenesis. First, an enhanced rate of lipid oxidation results in accumulation of acetyl-CoA, which is known to stimulate pyruvate carboxylase, the key enzyme of gluconeogenesis [15]. Second, accumulation of acetyl-CoA inhibits oxidation of pyruvate thereby providing more pyruvate for gluconeogenesis [16].

The reduction in BMR after improved glycaemic control was also associated with a reduction in the rates of hepatic glucose production and lipid oxidation. Under conditions of metabolic deterioration the increase in lipid oxidation may be necessary to compensate for the reduction in glucose oxidation [17]. The brain is dependent upon glucose as its energy source and this glucose could be provided by the enhanced rate of hepatic glucose production. On the other hand, it is not known whether the reduction in BMR observed during insulin therapy is due to a reduction in lipid oxidation or inhibition of the increased rate of gluconeogenesis.

Taken together the data from this study with simultaneous measurements of hepatic glucose production, BMR and lipid oxidation in non-obese Type 2 diabetic and healthy subjects demonstrate that these processes are interrelated. A reduction in hepatic glucose production is associated with a reduction in lipid oxidation, which in turn, will result in a reduction in BMR. This may help to explain the ease by which diabetic patients gain weight after improved glycaemic control.

Acknowledgements. This study was supported by grants from the Sigrid Jusélius Foundation, Finska Läkaresällskapet and the Nordisk Insulin Foundation. We wish to thank Johan Eriksson, Agneta Ekstrand, Carola Saloranta, Elisabeth Widén and Camilla Schalin-Jäntti for help with the studies.

\section{References}

1. Bogardus C, Taskinen MR, Zawadzki J, Lillioja S, Mott D, Howard B (1986) Increased resting metabolic rate in obese subjects with non-insulin-dependent diabetes mellitus and the effect of sulfonylurea therapy. Diabetes 35: 1-5

2. Goldner MG, Knaterud GL, Prout TE (1971) Effects of hypoglycemic agents on vascular complications in patients with adultonset diabetes mellitus. III. Clinical implications of UGDP results. JAMA 218: 1400-1410

3. Geldermans CA, Terpstra J, Krans HMJ (1975) The effect of phenformin-HCL on patients with diabetes mellitus, studied under strict balance conditions. Diabetologia 11: 475-484

4. DeFronzo RA (1988) The triumvirate: $\beta$-cell, musele, liver: a collusion responsible for NIDDM. Diabetes 37:667-683

5. Consoli A, Nurjhan N, Capani F, Gerich J (1989) Predominant role of gluconeogenesis in increased hepatic glucose production in NIDDM. Diabetes 38: 550-557

6. Ruderman NC, Toews JD, Shafrir E (1969) Role of free fatty acids in glucose homeostasis. Arch Intern Med 123: 299-313

7. Bogardus C, Lillioja S, Howard BV, Reaven G, Mott D (1984) Relationship between insulin secretion, insulin action, and fast- 
ing plasma glucose concentration in nondiabetic and noninsulin dependent diabetic subjects. J Clin Invest 74: 1238-1246

8. Blumenthal SA (1983) Stimulation of gluconeogenesis by palmitic acid in rat hepatocytes: evidence that this effect can be dissociated from the provision of reducing equivalents. Metab Clin Exp 32: 971-976

9. Golay A, Schutz Y, Felber JP, DeFronzo RA, Jéquier E (1986) Lack of thermogenic response to glucose/insulin infusion in diabetic obese subjects. Int J Obesity 10: 107-116

10. Ravussin E, Burnand B, Schutz Y, Jequier E (1982) Twenty-fourhour energy expenditure and resting metabolic rate in obese, moderately obese, and control subjects. Am J Clin Nutr 35: $566-573$

11. Ferrannini E (1988) The theoretical basis for indirect calorimetry: a review. Metabolism 37:287-301

12. Coleman TG, Manning RD Jr, Norman RA Jr, Guyton AC (1972) Dynamics of water-isotope distribution. Am J Physiol 223: $1371-1375$

13. Miles JR, Glasscock J, Aikens J, Gerich J, Haymond M (1983) A microfluorometric method for the determination of free fatty acids in plasma. J Lipid Res 24:96-99

14. Ravussin E, Bogardus C, Schwartz RS et al. (1983) Thermic effect of infused glucose and insulin in man. J Clin Invest 72 : 893-902
15. Williamson JR, Kreisberg RA, Felts PW (1966) Mechanisms for the stimulation of gluconeogenesis by fatty acids in perfused rat liver. Proc Natl Acad Sci USA 6: 247-254

16. Garland PB, Randle P (1964) Control of pyruvate-dehydrogenase in the perfused rat heart by the intracellular concentration of acetyl CoA. Biochem J 91: 6C-7C

17. Groop LC, Bonadonna RC, DelPrato Set al. (1989) Glucose and free fatty acid metabolism in non-insulin dependent diabetes mellitus: evidence for multiple sites of insulin resistance. J Clin Invest 84: 205-213

Received: 30 December 1991

and in revised form: 3 June 1992

Dr. L. Groop

Fourth Department of Medicine

Helsinki University Hospital

Unioninkatu 38

SF-00170 Helsinki

Finland 